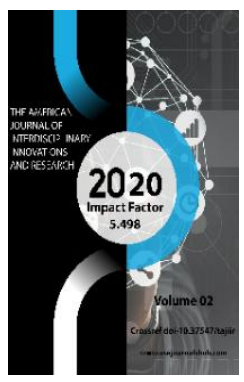

Journal Website: http://usajournalshub.c om/index,php/tajiir

Copyright: Original content from this work may be used under the terms of the creative commons attributes 4.0 licence.

\section{Digital Technology Is An Objective Need For A Universal Transition To Online Education Due To The Covid-19 Pandemic}

\author{
Nozima Fakhriddinovna Muratova \\ Associate Professor Of Uzbekistan Journalism \& Mass Communications University, Lector Of \\ Webster University In Tashkent, Uzbekistan \\ Khilola Batirovna Nikadambaeva \\ Associate Professor Of Uzbekistan Journalism \& Mass Communications University, Head Of \\ The Department Of Scientific Research, Innovation And Training Of Scientific And \\ Pedagogical Personnel, Uzbekistan
}

\title{
ABSTRACT
}

The article examines digital technology as an objective need for a universal transition to online education due to the COVID-19 pandemic. Particular attention is paid to the issues of increasing the role of online education during quarantine. And also, questions of creative and research knowledge of a modern journalist for the development of functional literacy and environmental competence in the process of teaching regional physical geography. An Internet-oriented electronic educational and methodological support has been developed, intended for students, undergraduates, teachers of higher and secondary specialized educational institutions, specialists, as well as for a wide range of readers interested in the geography of their native country. The article discusses the important principle of using electronic educational and methodological support "Physical Geography of Uzbekistan", that is, an automated training system in online learning.

\section{KEYWORDS}

COVID-19, online education, concept, intellectual knowledge, journalist, physical geography, region, natural resources, electronic teaching and methodological support, modern information technology, interactive, creativity, audiovisual conditions, independent education.

\section{INTRODUCTION}

COVID-19 is a global catastrophe for humanity and the whole world. The sudden quarantine of the coronavirus, the implementation of measures to combat the spread of infection has led to the growth of forced social distance learning and the transition from personal 
contacts to digital technologies. The changes affected not only secondary specialized but also higher education. The forced transition to digital education has served as an effective indicator of the opportunities and challenges of higher education. Teachers and students, on the one hand, got a chance to fully use modern digital technologies; on the other hand, they faced not only a lack of methodological developments in the field of distance learning, technological problems of the educational infrastructure, but also a lack of digital opportunities among students themselves. In addition, distance learning is still unusual and complex, from the point of view of psychological attitudes and preferences of students [9].

From this point of view, the COVID-19 crisis can be seen as the need for widespread use of technological processes and thinking models, which would normally take a long time. Nanyang Mansur Khamitov, a professor at Singapore University of Technology, said: "Higher education has experimented with distance learning in the past, but its adoption has been slow. COVID-19 has certainly provided a major breakthrough in which the vast majority of top universities around the world have made a rather dramatic shift towards full-scale distance learning [7].

\section{THE MAIN PART}

The concept of the development of the higher education system in Uzbekistan until 2030 was approved by the Decree of the President of the Republic of October 9, 2019 [1]:

In order to determine the priority areas of systemic reform of higher education in the Republic of Uzbekistan, to raise the process of training independently-minded highly qualified personnel with modern knowledge and high spiritual and moral qualities to a qualitatively new level, to modernize higher education, develop the social sphere and economic sectors based on advanced educational technologies: gradual transfer of the educational process of higher educational institutions to a credit-modular system;

- Introduction of advanced standards of higher education, in particular, a gradual transition from education, whose curricula are aimed at obtaining theoretical knowledge, to an education system aimed at developing practical skills, based on international experience;

- Raising the content of higher education to a qualitatively new level, establishing a system for training highly qualified personnel who can find their place in the labor market, make a worthy contribution to the stable development of the social sphere and sectors of the economy;

- Ensuring the academic independence of higher educational institutions;

- Phased implementation of the concept "University 3.0", which provides for a close relationship between education, science, innovation and activities for the commercialization of research results in higher educational institutions.

An important point of the Concept is the provision on increasing the level of enrollment in higher education for the strata of the population in need of social protection, including persons with disabilities, with the improvement of infrastructure conditions for them.

In addition, the President of Uzbekistan Shavkat Mirziyoyev, speaking on January 24 with a message to the parliament, proposed to declare 2020 as the "The Year of the Development of Science, Education and Digital Economy". The President signed a 
decree on the development of the digital economy and e-government. It is planned to double the share of the digital economy in Uzbekistan's GDP by 2023, and the share of electronic public services - to increase to $60 \%$ by 2022 . Centers for training digital knowledge will open in all regions of the country. And also, on April 28, was signed a decree "On measures for the widespread introduction of the digital economy and electronic government". The document provides for the accelerated formation of the digital economy with an increase in its share in the country's gross domestic product by 2023 by 2023. All health care institutions, schools, preschool education organizations, villages and makhallas must be connected to high-speed Internet in 2020-2021. The share of electronic government services is planned to be increased to $60 \%$ by 2022 . The decree also provides for the development of "digital entrepreneurship" with an increase in the volume of services in this area by 2023 by and bringing their exports to $\$ 100$ million. The widespread introduction of digital technologies is planned at all stages of the education system. By 2022, digital knowledge training centers will open in all regions of the country as part of the Five Initiatives project $[6 ; 10]$.

\section{RESULTS AND DISCUSSION}

The proposed work includes the introduction of computer technology in the teaching of the subject of regional physical geography of countries, on the example of teaching physical geography of Uzbekistan. An Internetoriented electronic educational and methodological support has been developed, intended for students, undergraduates, teachers of higher and secondary specialized educational institutions, specialists, as well as for a wide range of readers interested in the geography of their native country [2]. The idea of the development is the design of computer simulation of classes using interactive methods and technologies when teaching this subject. An individual and differentiated approach to training is taken into account. The programs are presented in the form of multimedia textbooks designed to be studied in the classroom, on electives and to test knowledge. And also for use as a reference and visual aid in self-study. Teaching methods are proposed through the interaction of the student with educational resources with minimal participation of the teacher. These are teaching materials delivered over computer networks, such as online databases, electronic journals, and computer-based tutorials. The development of these methods is characterized by a multimedia approach, when educational resources are created with the help of various means: print, audio, video materials, fact-checking, contexts, podcasts, the Streisand effect, which is especially important for the development of e-learning for the journalist.

Despite a number of positive shifts that have taken place in the higher education system, the problems of obtaining a quality education still remain. The best way to get a quality education is to activate trainees, initiate their creative cognitive activity in the organization of all forms of classes, and gradually involve trainees in direct participation in scientific research. It is such specialists who, using the example of journalism, who have received a high-quality fundamental education, are able to generate new knowledge and create new technologies in science and production.

The formation of journalistic thinking that meets the requirements of the present, and the preparation of a journalist for practical activities in accordance with the needs of the 
functioning and prospects of transforming the mass media system is a task whose successful solution depends on a set of conditions. These include the development of natural abilities and inclinations of a future specialist, the formation and improvement of a system of specific professional qualities, a variety of creative skills, methods of action, organizational and editorial work techniques, methodology, methods and techniques for collecting and processing information, creating works, arranging them in issues, programs and numbers. The way to this is to study the block of academic disciplines, get acquainted with the experience accumulated in the editorial offices, taking into account the constant focus on the practical implementation of the knowledge and skills acquired. Practical activity in journalism, considered, verified and corrected from the standpoint of modern achievements of journalistic science, is necessary from the very beginning. Only in the dialectical interaction of theory and practice, when theory generalizes practice, and practice serves as a support for theory and a criterion for its truth, the development of the creative potential of a journalist takes place [4].

Since a journalist is a universal specialty, who must know everything and always, especially the geography of his native land, we offer electronic educational and methodological support (EEMS) "Physical Geography of Uzbekistan", i.e. automated training system. EEMS is a scientific result, information learning is a purposeful, interactive, asynchronous process of interaction between subjects and learning objects with each other and with learning tools, and the learning process is invariant to their location in space and time. The educational process of information learning takes place in a specific didactic system, the elements of which are subsystems: learning objectives, learning content, teaching methods, teaching aids, organizational forms of learning identification-control, educational-material.

The proposed system of specific principles includes the principles of pedagogical expediency, such as the use of new information technologies, openness of teaching, interactivity, starting level, regulation, individualization. One of the important principles of the formation of geographic potential is visibility, which is due to the peculiarities of the perception and development of the student's thinking. A person draws his knowledge from the outside world with the help of his senses, and visual aids serve as a source of information for him.

The main types of work are the formation of skills in working with information, analysis, modeling, forecasting, dialogue communication, working in groups, research, project activities. The main activities are individual, independent, creative, discussion, dialogue, communicative. It should be noted that at each stage of the study of the regional physical geography of Uzbekistan, local history material is used, as this contributes to the activation of the mental activity of students. They learn to compare the characteristics of the components of the nature of their region with the components of the nature of other territories, to use the local history material as a starting point for posing questions and tasks of a problematic nature, creating problem situations. Local lore material is also used as a source for practical and independent work, demonstration of natural local objects, models, samples of rocks and minerals, collections of soils, plants, since performing independent work on the characteristics of objects, phenomena, 
processes is important for studying the subject with the aim of determining the relationship between man and nature [5].

In the process of online education, a teacher in his activities meets such students who feel difficulties in mastering a lecture, not being able to use a computer or the Internet. As knowledge accumulates, it turns out that many students are not able to master it. They have a negative attitude towards the subject, as well as a kind of psychological barrier to the teacher.
The use of modern information technologies made it possible, in the process of assimilating new knowledge, to significantly increase attention and memorability, while significantly reducing the duration of the process of transferring knowledge from teacher to student. The use of various computer programs helped students to independently complete the assignments, as well as to repeat the materials covered. Further on the main menu, you can select the topic of the desired lecture (Fig. 1).

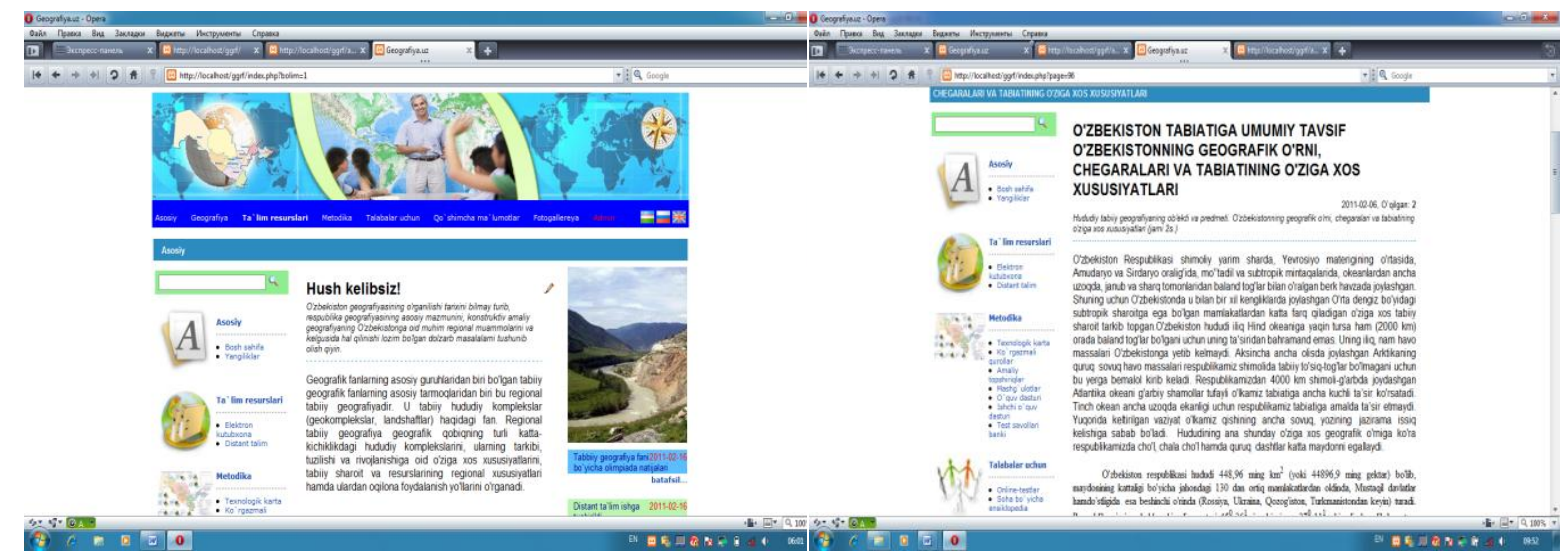

1-fig. Main menu. Lecture content window

When studying a new topic in the classroom, illustrated, animated presentations are actively used, which are equipped with narration, a variety of cards and videos, students independently or with the help of questions ponder conclusions, make generalizations and conclusions, they develop memory, speech and imagination.

The effectiveness of any type of training depends on a number of components: the technical base, the effectiveness of the allowing the student to achieve a deeper memorization of educational material through imaginative perception and emotional impact. Observing the demonstrated objects, developed methodological materials, training technologies used in the organization of training. The development and application of computer training programs and new information and educational tools is organically included in modern teaching technologies. It is the teacher, like no one 
The American Journal of Interdisciplinary Innovations and Research (ISSN-2642-7478)

Published: September 19, 2020 | Pages: 10-17

Doi: https://doi.org/10.37547/tajiir/Volume02Issue09-02

else, who can accurately determine to what extent and at what specific stage the computer is able to facilitate students' assimilation of knowledge. Many related issues can be resolved only as a result of assessing the student's lively reaction (Fig. 2).

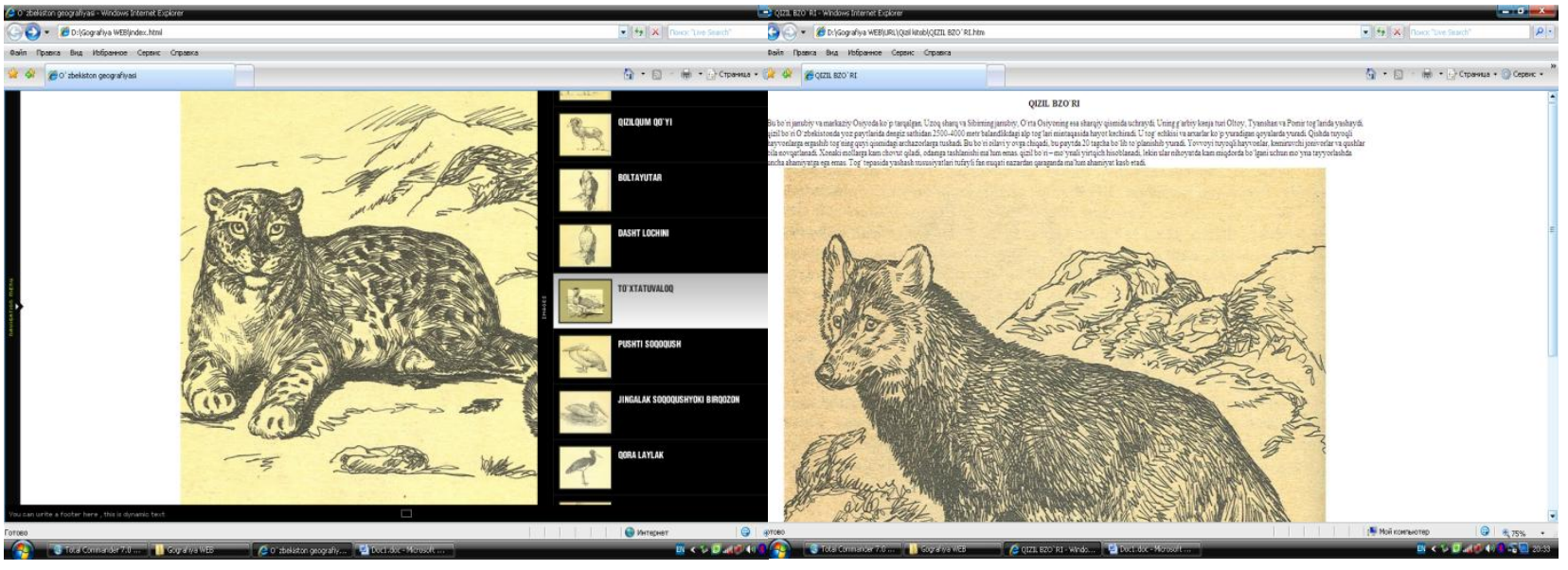

2-fig. Fauna photo galleries

Interactive databases organize data sets that can be accessed through telecommunications. Using these resources, course developers, for example, can maintain local databases for both students and teachers (Figure 3)

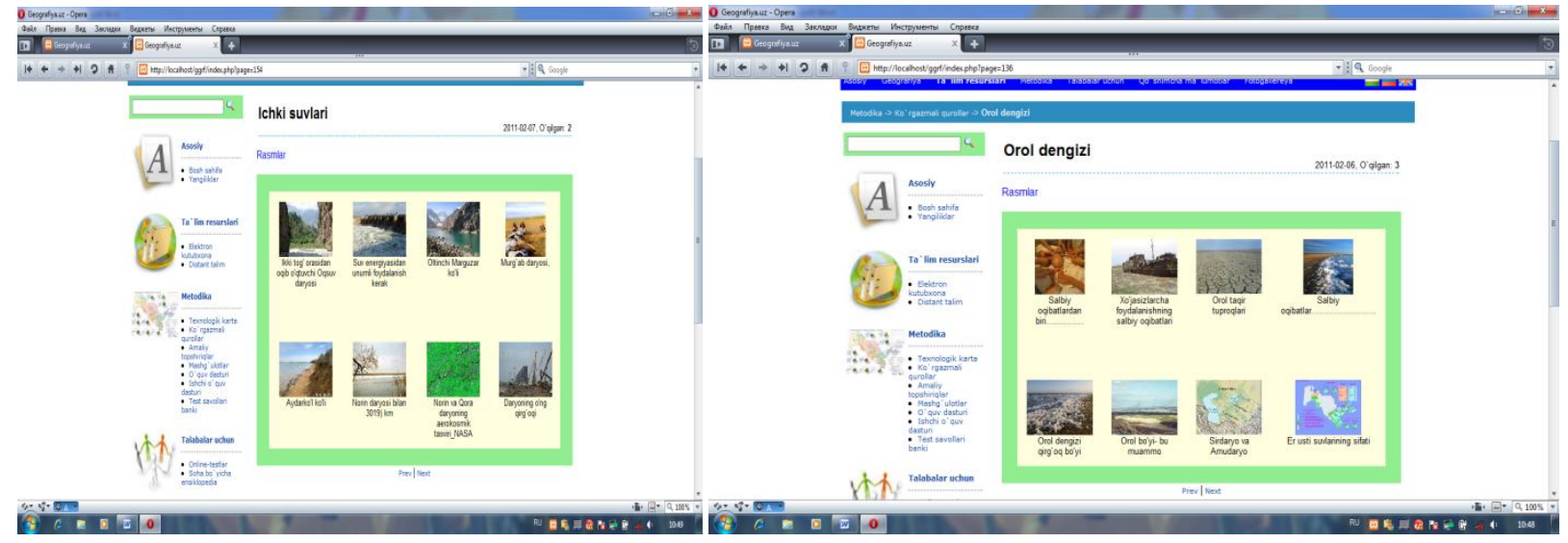

-fig. Internal waters of Uzbekistan and the Aral Sea 
Online technologies, it is necessary to introduce new formats and technologies for delivering knowledge, and to deeply change the value-semantic content of education (Fig. 4).

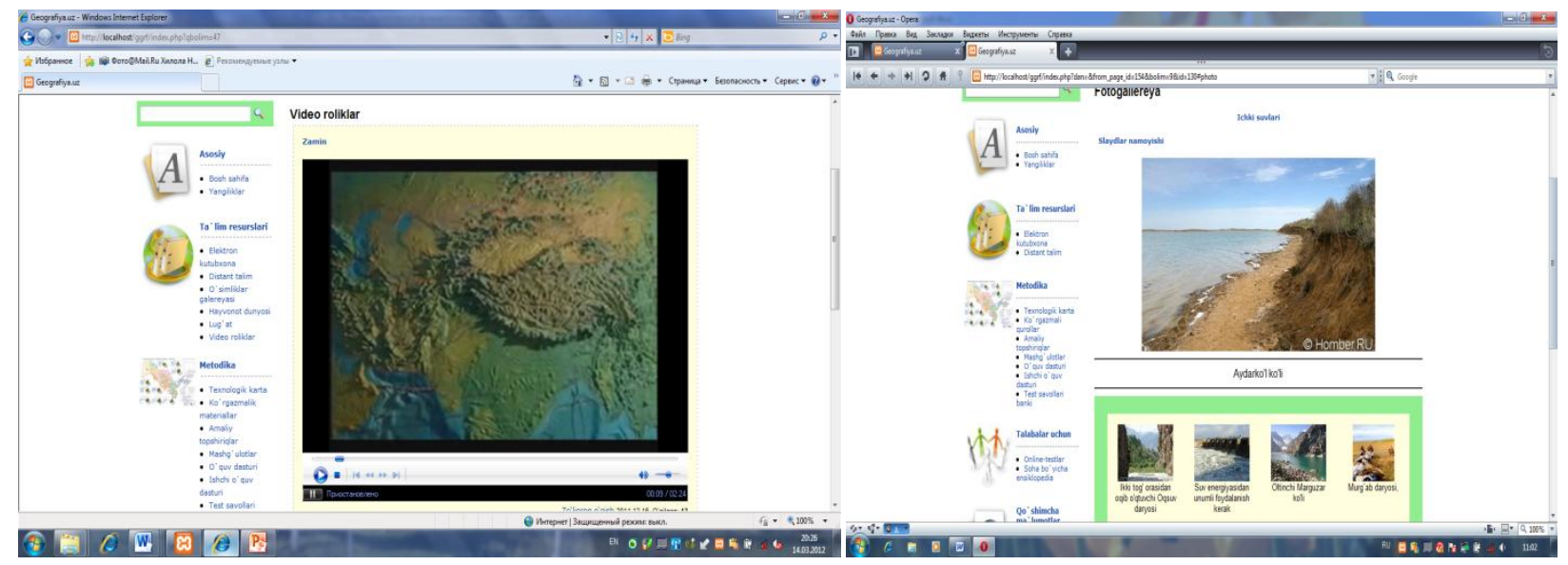

4-fig. Video window

One of the biggest obstacles to meaningful change is always what we call an organizational structure, which involves invisible boundaries between departments. During the current crisis, such a goal was promptly set by universities: to help prevent the spread of coronavirus on campuses and ensure continuity of learning. However, there is another obstacle - the human factor or the inertia of the academic community itself. In "peacetime" times, when only a small part of this community had experience of distance teaching and the desire to implement it further, a general transition to online was not possible [7].

\section{CONCLUSION}

In conclusion, we can say that the unbiased need for a universal transition to online because of COVID-19, which did not threaten the mainstream of education, pushed all these technical, methodological and other concerns and risks to the background, teachers who had previously resisted the new format suddenly began to receive satisfaction from growth their new competencies. They have found that they can use online technology creatively and are likely to incorporate it into their future practice, which could be called hybrid or blended learning, the emergence and dominance of which in the post-pandemic period is almost unrecognized. All this testifies to the necessity and possibility of changing the existing paradigm of thinking; it will be built on a new philosophy of education.

The positive side of the catastrophe is its constant ability to transform something that was once considered impossible into an aspect of a new reality. This is exactly what has happened in higher education. The debate about the viability of universities moving to a virtual learning environment, as mentioned above, has been going on for a long time more than ten years. After COVID-19 made itself known and began to spread across the planet, the most constructive results of this controversial discourse were transferred to 
the practice of many countries within just one week. COVID-19 developed so rapidly that there was not even time to postpone online training until later [6].

Thus, EEMS, i.e. an automated training system should be considered as a training information environment, which is an organic continuation of traditional teaching methods based on a book, and which, due to the intellectual specific abilities of personal computers, provides:

- Continuous improvement of the educational process: the introduction of innovative technologies, the development of educational and methodological complexes based on the use of information technology based on multimedia technology;

- Democratization of the higher education system;

- Expansion of the test base in fundamental subjects to volumes that provide both coverage of all topics and the individuality of knowledge control tasks;

- Creation of methodologically grounded sets for all forms of control: intermediate, current and final;

- Fast and complete access to any information in hypertext mode;

- Helping students in organizing independent work;

- Ability to perform practical work, which can be mainly implemented through the use of a personal computer;

Audiovisual conditions such as graphics, video, audio, didactic materials, as well as factchecking, contexts, podcasts, the process of the Streisand effect, which serve to gain new knowledge of critical thinking through similarity by analogy, bringing the motivational and informational components of behavior from different hemispheres into a single one activity.

\section{REFERENCES}

1. Decree of the President of the Republic of Uzbekistan "On approval of the concept of development of the higher education system of the Republic of Uzbekistan until 2030". National database of legislation, 09.10.2019, № 06/19/5847/3887; 30.04.2020., № 06/20/5987/0521.

2. Nikadambaeva Kh.B. Copyright certificates of the State Patent Office and the Intellectual Property Agency of the Republic of Uzbekistan. - T .: 2012.

3. Nikadambaeva Kh.B. Methods of using computer technology in teaching the subject "Natural Geography of Uzbekistan" (on the example of the higher education system). Monograph. -T $\therefore$ A classic word. 2015. P.264.

4. Prokhorov E.P. An Introduction to Journalism Theory: A Textbook. $-M$ : Aspect Press, 2009. P.351.

5. Khasanov I., Nikadambaeva Kh.B. Physical geography of Uzbekistan. Educationalmethodical manual. Tashkent, University, 2017. P.252.

6. https://www.pv.uz/ru/news/prezidentshavkat-mirzieev-obratitsja-k-olijmazhlisu-s-ocherednym-poslaniem/.

7. https://lex.uz/ru/docs/4545887/.

8. http://www.tsu.ru/university/rector_page /mirovoe-vysshee-obrazovanieparadoksy-pandemii/.

9. https://review.uz/ru/post/globalnoevliyanie-covid19-na-sistemuobrazovaniya/.

10. https://www.gazeta.uz/ru/2020/04/29/digi tal/ 